\title{
The progress of financial market integration in East Asia
}

\begin{abstract}
The study investigates the progress of financial market integration in selected East Asian countries after the 1997 financial crisis. Adopting Johansen (Econometrica 59:1551-1580, 1991) multivariate cointegration on the region's credit and stock markets, the study finds only partial cointegration in both markets which imply a low level of integration. However, for regional stock markets, the result suggests that the level of integration has been improving after the crisis.
\end{abstract}

Keyword: East Asia; Financial market; Integration; Cointegration 